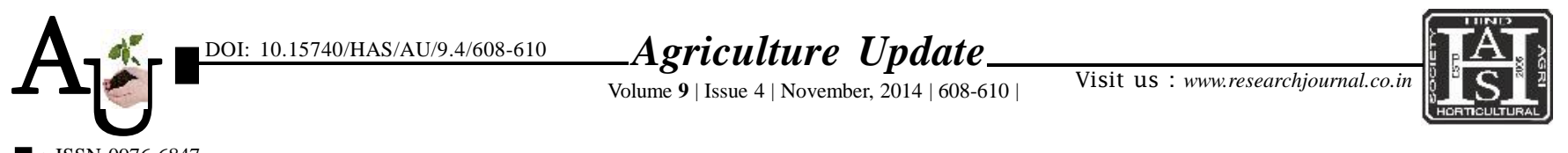

e ISSN-0976-6847

Research Note

\title{
Evaluation of yield of maize through improved variety
}

\section{A.D. RAJ, V. YADAV, H.R. JADAV AND J.H. RATHOD}

Article Chronicle :

Received :

19.09.2014;

Accepted :

30.10.2014

\section{KeY Words :}

Front line

demonstration,

Improved variety,

Maize
Author for correspondence :

\section{YADAV}

Krishi Vigyan Kendra

(N.A.U.), DEDIAPADA

(GUJARAT) INDIA

Email: vikas.yadav15

@yahoo.com,

vikasyadav.hort

@gmail.com

See end of the article for

authors' affiliations
SUMMARY : The study was carried out during Kharif season of 2011, 2012 and 2013 in seven villages of Narmada district. In all 32 demonstrations on maize crop were carried out in area of 11.6 ha with the active participation of farmers with the objective to demonstrate the latest technology of maize production potential. The improved technology consisting of suitable variety 'Gujarat Maize 6'. The results revealed that FLD recorded higher yield as compared to farmers practice over the years of study. The improved variety recorded average yield of $1409 \mathrm{~kg} / \mathrm{ha}$ which was 18.5 per cent higher than that obtained with farmers practice of $1189 \mathrm{~kg} /$ ha. In spite of increase in yield of maize, technological gap, extension gap and technology index existed which was $1034,219 \mathrm{~kg} / \mathrm{ha}$ and 42.3 per cent, respectively. The improved variety gave higher gross return of $15030 \mathrm{Rs} . / \mathrm{ha}$, net return of $4031 \mathrm{Rs}$./ha with benefit cost ratio 1.4 as compared to local check (12688 Rs./ha, $2289 \mathrm{Rs} . / \mathrm{ha}$ and benefit cost ratio 1.2).

How to cite this article : Raj, A.D., Yadav, V., Jadav, H.R. and Rathod, J.H. (2014). Evaluation of yield of maize through improved variety. Agric. Update, 9(4): 608-610. 